\title{
FISH NUTRITION: BIBLIOMETRIC ANALYSIS IN BRAZIL AND THE WORLD
}

\author{
Marcelo Fanttini POLESE ${ }^{1}$, Eduardo SHIMODA ${ }^{2}$, Shaytner Campos DUARTE ${ }^{3}$, Pedro Pierro \\ MENDONÇA $^{4}$, Marcella Costa RADAEL ${ }^{5}$, Jonas Henrique de Souza MOTTA ${ }^{6}$, André Batista de SOUZA ${ }^{1}$ \& \\ Manuel Vazquez VIDAL JÚNIOR ${ }^{6}$
}

\author{
${ }^{1}$ Instituto Federal do Espírito Santo - Campus Piúma, ES, Brasil. \\ ${ }^{2}$ Universidade Cândido Mendes - Campos dos Goytacazes, Rio de Janeiro, Brasil. \\ ${ }^{3}$ Faculdade de Medicina de Campos. Campos dos Goytacazes, RJ - Brasil. \\ ${ }^{4}$ Instituto Federal do Espírito Santo - Campus Alegre, Distrito de Rive, Alegre, ES, Brasil. \\ ${ }^{5}$ Universidade Vila Velha, Vila Velha, ES, Brasil. \\ ${ }^{6}$ Universidade Estadual do Norte Fluminense Darcy Ribeiro, CCTA/ LZNA, Campos dos Goytacazes, RJ, Brasil. \\ *Autor para correspondência: marcelopolese@ hotmail.com
}

http://dx.doi.org/10.18571/acbm.101

\begin{abstract}
The Science of fish nutrition is an important issue and of great importance from the point of view of developing new diets with respect to the nutritional requirements of various fish species and the environment, with many published articles addressing the subject. The objective of this study was to make a bibliometric analysis to identify trends in publications worldwide and in Brazil. Took place during the month of December 2011, searches the Scopus base and recorded information related to the main countries, authors, publishing and institutions vehicles. The study revealed that Brazil, besides occupying Featured number of articles on the subject, including having a center of excellence in the subject, presented high growth rates of articles, compared to global rates. Further, it was found that most of the articles on the topic is concentrated in a few authors, institutions and journals.
\end{abstract}

Keyword: Food; Bibliometrics; Research; Fish Farming.

\section{RESUMO}

A nutrição de peixes é uma importante área e de grande relevância do ponto de vista do desenvolvimento de novas dietas com relação às exigências nutricionais de diversas espécies de peixes e do ambiente, com muitos artigos publicados abordando o assunto. $\mathrm{O}$ objetivo deste estudo foi fazer uma análise bibliométrica para identificar tendências em publicações em todo o mundo e no Brasil. Foi realizado durante o mês de Dezembro de 2011, uma busca na base Scopus e informações registradas relacionadas com os principais veículos de países, autores, editoras e instituições que publicam sobre esse tema. O estudo revelou que o Brasil, ocupa uma posição de destaque na publicação de artigos sobre o assunto, indicando ser um centro de excelência no assunto, apresentado altas taxas de crescimento de artigos, em comparação com as taxas globais. Além disso, verificou-se que a maioria dos artigos sobre o tema concentra-se em poucos autores, instituições e revistas.

Palavras-chave: Alimentos; Bibliometria; Pesquisa; Criação de peixes. 


\section{Introduction}

Fish farming requires the adoption of managed breeding systems in intensive systems where nutrition plays the most important role, requiring serious efforts of research for the generation of appropriate technologies. The few surveys so far conducted in the country on the subject deal, mostly the result of adaptations of international research to our conditions (PORTZ, 2001).

The fish nutrition is a science that has been growing steadily due to various factors, such as growth of the world and national aquaculture, new species of potential fish for fish farming, industry by-products of use to feed formulations, achieve better digestibility coefficients, greater environmental responsibility, among other factors (COLT, MONTGOMERY, 1991; PORTZ, 2001; WATANABE et al., 1991). Research in this area are important for the development of fish farming in Brazil and worldwide (OLIVEIRA; DÓREA; DOMENE, 1992; PORTZ, 2001).

Thus, the qualitative and quantitative analysis of publications on a particular subject is an indicator of the relative importance attached to this issue (ARAÚJO, 2006; BOUSTANY, 1997; FONSECA, 1986). A science that has attracted most attention recently is bibliometrics (PINHEIRO, 1983). From this it is possible, by applying statistical methods to make findings about the state of a given art, science or business (PRITCHARD, 1969; ROSTAING, 1996; TAGUE-SUTCKIFFE, 1992).

The objective of this study was therefore to carry out a bibliometric study using the Scopus search base, on the subject nutrition of fish, both in Brazil and in the world and presented the evolution and countries, authors, institutions and journals What else have published on the subject.

\section{Material and Methods}

The data used in this study were obtained from the base of search scientific articles Scopus, available on Portal Journals Capes. The search was held on December 17, 2011, and used the option of quick search, which returns the publications that have the word you typed in the title, abstract or keywords.

Information regarding the temporal evolution, name of authors, journal, affiliation and country were obtained in the fields where you can refine the search.

For temporal analysis were exponential regression equations the number of publications under the year. The values of each variable were linearized by applying logarithm so that the slope of the equation indicates the growth rate in a given period.

The concentration analysis was performed by comparing the number of publications of the top 10 contributors (countries, authors, institution or journal) out of the total of publications between the years 2000 to 2010 .

\section{Results and discussion}

Looking at Figure 1, it is clear that Brazil has, in the course of time, increased their percentage share in the total number of publications compared to the world. In 2000, the Brazilian papers accounted for approximately $1.25 \%$ of total production in the world. In 2010, Brazil published around $2.3 \%$ of the world's goods, and the Brazilian representative has shown exponential growth. 

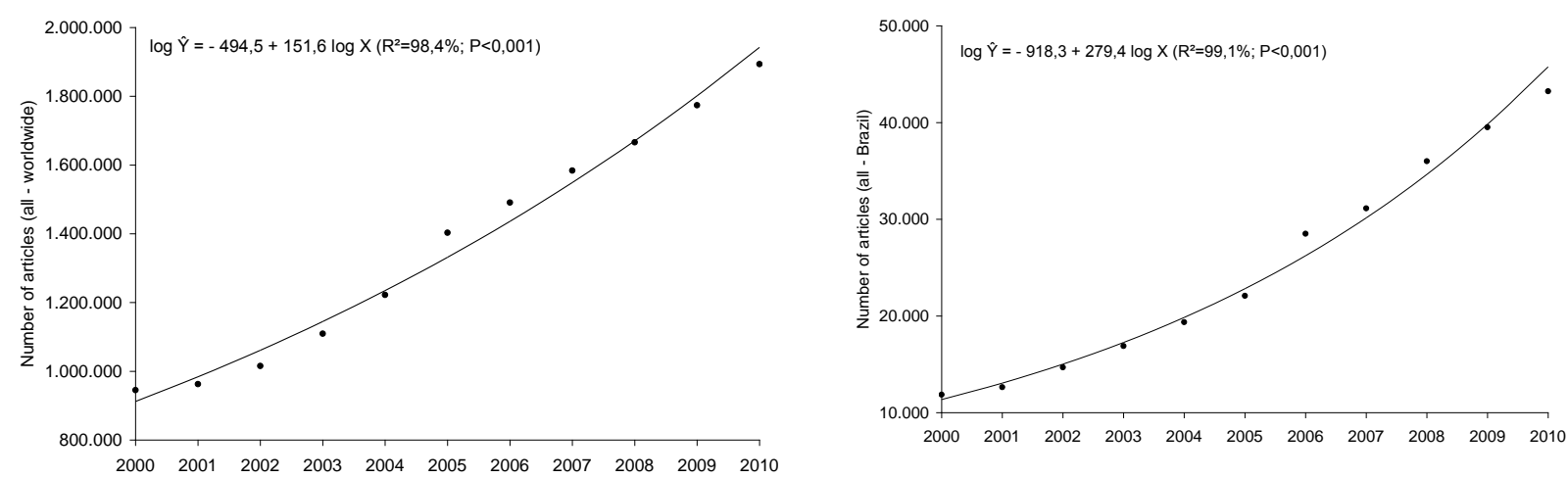

Figure 1: Evolution of the number of total publications in the world and in Brazil during the period 2000 to 2010.

\subsection{Articles by country - concentration and temporal}

Analysis Table 1 shows the 10 countries that have published articles in the world, both in general (fish), as those specific about fish nutrition. One can see that the United States and the United Kingdom are the ones who produce scientific articles. Although the UK take second place in publications with fish nutrition and fish, this is still well below the number of posts compared to the United States.

Brazil is in 10th place in the scientific production of articles in the fish area, but when you look at the scientific production in fish nutrition area, it occupies the 7th place as seen in Table 1, one explanation for this increase is the need to research the nutritional requirements of new species of native fish, with great potential for the Brazilian fish farming.

Table 1: Countries most published articles in Scopus, in the area of fish and fish nutrition.

\begin{tabular}{cccc}
\hline Country & Fish & \multicolumn{2}{c}{ Fish Nutrition } \\
\hline United States & $\mathbf{N}^{\mathbf{0}}$ & Country & $\mathbf{N}^{\mathbf{0}}$ \\
United Kingdom & 34142 & United States & 321 \\
Canada & 9879 & United Kingdom & 117 \\
Japan & 9257 & Spain & 97 \\
Australia & 8731 & France & 93 \\
France & 5920 & Australia & 78 \\
Spain & 5212 & Canada & 76 \\
Germany & 4976 & Brazil & 71 \\
Norway & 4856 & Norway & 71 \\
Brazil & 4687 & Germany & 59 \\
\hline
\end{tabular}

Figure 2 shows the evolution of the number of articles related to publications with fish and fish nutrition in the world from 2000 to 2010, demonstrating that the publications in the world regarding fish had a linear growth, unlike when observing the publications fish nutrition had a very large fluctuation in recent years and may be inferred that the continuation of research in fish nutrition area was not very efficient in the private and public incentives. 

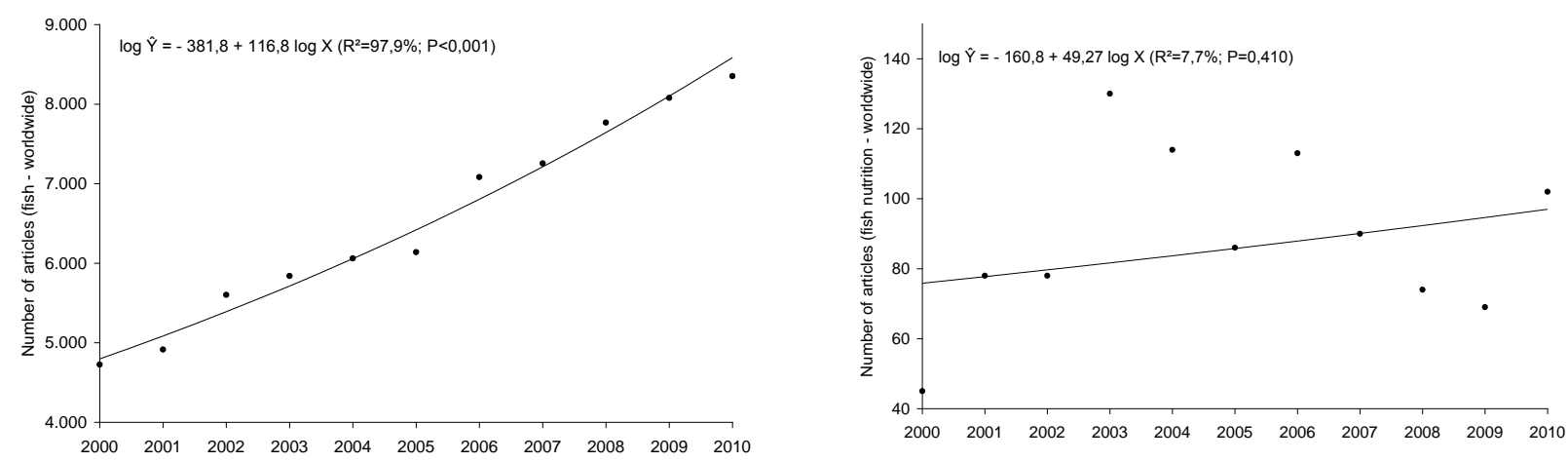

Figure 2: Evolution of the number of publications on the subject of fish nutrition and fish during the period 2000 to 2010 in the world.

\subsection{Articles per author - concentration}

Table 2 presents the main authors who have published articles on fish and fish nutrition in Brazil and worldwide. It is noticed that, despite Brazil have good participation in related publications to the subject, yet there is a great concentration of articles concentrated in a few authors. This information demonstrates the great difficulty of newly doctors to raise funds in development agencies to join the search, even as their resumes are not compatible with traditional and well-established researchers.

Table 2: Key authors who have published articles about the area of fish and fish nutrition in Brazil and worldwide.

\begin{tabular}{|c|c|c|c|c|c|c|c|}
\hline \multicolumn{2}{|l|}{ Fish } & \multicolumn{2}{|l|}{ Fish - Brazil } & \multicolumn{2}{|c|}{ Fish Nutrition } & \multicolumn{2}{|c|}{ Fish Nutrition - Brazil } \\
\hline Author & $\mathbf{N}^{\mathbf{o}}$ & Author & $\mathbf{N}^{\mathbf{o}}$ & Author & $\mathbf{N}^{\mathbf{o}}$ & Author & $\mathbf{N}^{\circ}$ \\
\hline Wood, C.M. & 210 & Oliveira, C. & 56 & Gatlin, D.M. & 12 & Pezzato, L.E. & 8 \\
\hline Moravec, F. & 202 & Bertollo, L.A.C. & 55 & Shiau, S.Y. & 11 & Barros, M.M. & 6 \\
\hline Dabrowski, K. & 144 & Agostinho, A.A. & 54 & Kaushik, S.J. & 9 & Donzele, J.L. & 6 \\
\hline Klesius, P.H. & 132 & Foresti, F. & 53 & Donzele, J.L. & 9 & Goncalves, G.S. & 5 \\
\hline Benjakul, S. & 129 & Baldisserotto, B. & 52 & Pezzato, L.E. & 9 & Guimaraes, I.G. & 4 \\
\hline Johnston, I.A. & 128 & Sazima, I. & 45 & Williams, K.C. & 9 & Boscolo, W.R. & 4 \\
\hline Cooke, S.J. & 119 & Val, A.L. & 43 & Allan, G.L. & 8 & Cyrino, J.E.P. & 4 \\
\hline Farrell, A.P. & 117 & Moreira-Filho, O. & 42 & Conceicao, L.E.C. & 8 & Feiden, A. & 3 \\
\hline Potter, I.C. & 113 & Takemoto, R.M. & 39 & Bell, J.G. & 8 & Moraes, G. & 3 \\
\hline Gatlin, D.M. & 113 & Luque, J.L. & 38 & Dick, J.R. & 8 & Chagas, E.C. & 3 \\
\hline
\end{tabular}

In 2000, Brazil accounted for approximately $2.5 \%$ of the total number of publications related to fish, compared to the rest of the world, in 2010 the investment is now approximately $6 \%$, showing that interest in research in the area of fish has increased greatly over the last 10 years, but nothing compared to the increase of production in the country was close to $10 \%$ per year. 

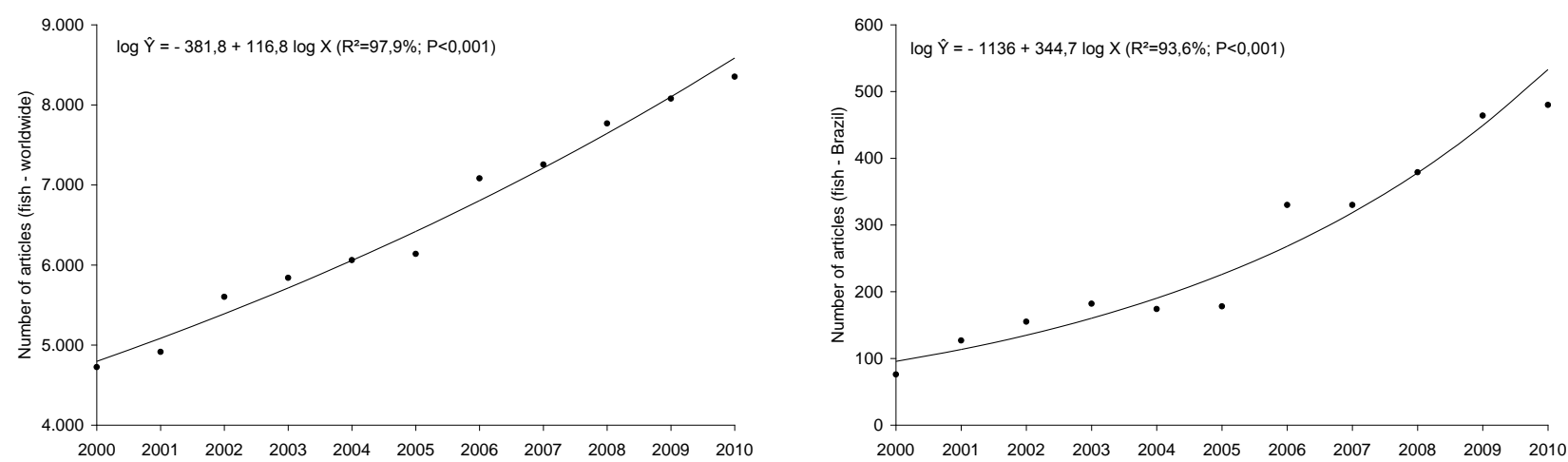

Figure 3: Evolution of the number of fish theme relates to publications in the world and in Brazil during the period from 2000 to 2010 .

\subsection{Publishing vehicle (journal, conference proceedings, etc.)}

Table 3 shows the major magazines that are published work on fish and fish nutrition in the world and in Brazil.

Table 3: Main vehicles more published about fish and fish nutrition in the world and in Brazil.

\begin{tabular}{|c|c|c|c|c|c|c|c|}
\hline \multicolumn{2}{|l|}{ Fish } & \multicolumn{2}{|l|}{ Fish - Brazil } & \multicolumn{2}{|l|}{ Fish Nutrition } & \multicolumn{2}{|c|}{$\begin{array}{l}\text { Fish Nutrition - } \\
\text { Brazil }\end{array}$} \\
\hline Periodic & $\mathbf{N}^{\mathbf{0}}$ & Periodic & $\mathbf{N}^{\mathbf{0}}$ & Periodic & $\mathbf{N}^{\mathbf{o}}$ & Periodic & $\mathbf{N}^{\mathbf{o}}$ \\
\hline Aquaculture & 5998 & Neotrop. ichthyol. & 216 & Aquaculture & 153 & $\begin{array}{l}\text { Rev. bras. } \\
\text { zootec. }\end{array}$ & 21 \\
\hline J. fish biol. & 4819 & Braz. j. biol. & 205 & Hydrobiologia & 78 & Hydrob. & 8 \\
\hline Environ. biol. Fishes & 2884 & Acta sci., Biol. sci. & 167 & Aquac. res. & 50 & PAB & 5 \\
\hline Hydrob. & 2422 & J. fish biol. & 139 & Aquac. nutr. & 47 & Aquaculture & 4 \\
\hline Nature & 2384 & Rev. bras. zootec. & 117 & Lipids & 47 & Cienc. rural & 4 \\
\hline Mar. ecol., Prog. ser. & 2012 & Aquaculture & 90 & J. Great Lakes res. & 46 & Sci. agric. & 3 \\
\hline $\begin{array}{l}\text { Can. j. fish. aquat. } \\
\text { sci. }\end{array}$ & 1872 & $\begin{array}{l}\text { Environ. biol. } \\
\text { fishes }\end{array}$ & 88 & Am. j. clin. nutr. & 40 & $\begin{array}{c}\text { Acta sci., Anim. } \\
\text { sci. }\end{array}$ & 3 \\
\hline Fish. res. & 1711 & Genetica & 78 & $\begin{array}{l}\text { J. Am. Diet. } \\
\text { Assoc. }\end{array}$ & 40 & Aquac. res. & 3 \\
\hline J. Exp. Biol. & 1704 & Hydrob. & 76 & J. nutr. & 31 & $\begin{array}{l}\text { Acta sci., Biol. } \\
\text { sci. }\end{array}$ & 2 \\
\hline Aquac. res. & 1625 & Caryologia & 67 & Rev. bras. zootec. & 27 & Aquac. nutr. & 2 \\
\hline
\end{tabular}

This information is especially important in order to choose which publication vehicle to submit an article. As noted, the magazine that have more articles on fish and fish nutrition in the world is the Aquaculture, different publications in Brazil, in the area of fish and fish nutrition this magazine is in sixth and fourth place respectively. Several publications in the areas of fish and fish nutrition in Brazil are in multidisciplinary journals, unlike most of the publications in the same area in the rest of the world, who choose to journals in aquaculture area. This is a practice that may hinder the diffusion of relevant work in the area of interest.

By Figure 4 we can see that in Brazil in 2000 to participate in publications was approximately $2.5 \%$, while in 2010 was $18 \%$, showing that the interest of researchers and funding agencies to define research nutritional requirements of the species native to Brazil caused the growth of publications in the grow area, highlighting Brazil on the world stage. 

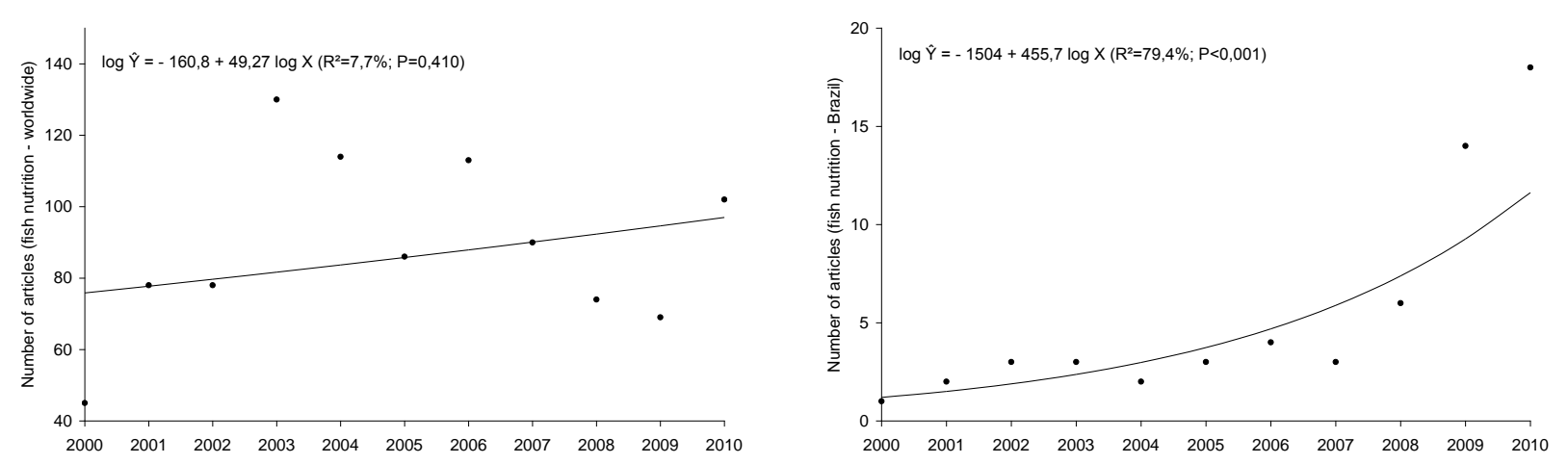

Figure 4: Evolution of the number of fish nutrition issue of respect to publications in the world and in Brazil during the period 2000 to 2010 .

\subsection{Articles by the institution - concentration}

Table 4 shows that most institutions have published about fish and nutrition fish in the world and in Brazil. Interestingly, the institution that stands out in the world with publications in fish nutrition area is the UNESP, ranking third, as in Brazil ranking first, making a reference centre in fish nutrition area in Brazil and in the world. Another aspect that can be noted is that when it comes to the subject fish to publications, no Brazilian institution appears among the 10 that publish more, showing that Brazil is still far behind the world stage when it comes to fish with publications. Still, you can see the extreme concentration of articles around the few institutions in Brazil.

Table 4: Major institutions that more published about fish and fish nutrition in Brazil and worldwide.

\begin{tabular}{cccccccc} 
Fish & \multicolumn{3}{c}{ Fish - Brazil } & Fish Nutrition & \multicolumn{2}{c}{$\begin{array}{c}\text { Fish Nutrition - } \\
\text { Brazil }\end{array}$} \\
Institution & $\mathbf{N}^{\mathbf{0}}$ & Institution & $\mathbf{N}^{\mathbf{0}}$ & Institution & $\mathbf{N}^{\mathbf{0}}$ & Institution $^{\mathbf{N}}$ \\
\hline Hokkaido Un. & 1289 & UNESP & 571 & Un. Stirling & 28 & UNESP & 18 \\
Un. Washington & 1175 & USP & 448 & NIFES & 21 & UEM & 9 \\
Un. British Columbia & 1136 & UEM & 342 & UNESP & 20 & Inst. Pesca & 7 \\
Un. Tokyo & 1119 & UFSCar & 251 & US Geol. Survey & 19 & USP & 6 \\
US Geol. Survey & 1080 & INPA & 247 & CSIRO & 18 & Unioeste & 5 \\
IMR & 1074 & UFRJ & 174 & Texas Un. & 16 & UFV & 5 \\
UC Davis & 1016 & Unicamp & 158 & Taiwan Ocean Un. & 16 & INPA & 5 \\
Oregon State Un. & 967 & UFPR & 156 & INRA - IFREMER & 16 & UFRJ & 4 \\
Tokyo Un. Mar. Sc. & 899 & UFSC & 131 & Univers. Bergen & 15 & Embrapa & 4 \\
Univers. Bergen & 884 & UFRGS & 118 & Un. Algarve & 14 & Governo SP & 4 \\
\hline
\end{tabular}

From Chart 1, we can see that the top 10 countries participated in approximately 72 publications and $74 \%$ in the areas of fish and fish nutrition, respectively. Demonstrating that research is highly concentrated in a few countries.

Top 10 Brazilian authors account for $64 \%$ of all national publications in fish nutrition area, publications in this area are directly related to a minority of researchers, and the part of nutritional requirements is an important basis for technology package of a new species of fish.

Another aspect that can be seen in chart 1, there is high concentration of Brazilian publications in fish nutrition area in major newspapers, magazines and the top 10 account for over $74 \%$ of the publications in this area. This result shows the major journals that researchers publish more of this evaluation by other researchers can be directed in which search or publish periodicals in the world or in Brazil in fish nutrition area. 
The high concentration of publications in fish nutrition area in 10 leading journals, authors and countries is even greater when it evaluates the top 10 Brazilian institutions that publish in this area, from 94\%, few institutions publish almost all Articles aimed at fish nutrition area, watching as soon as the encouragement to researchers and institutions to work the line of research on fish nutrition area is poorly distributed in Brazil.

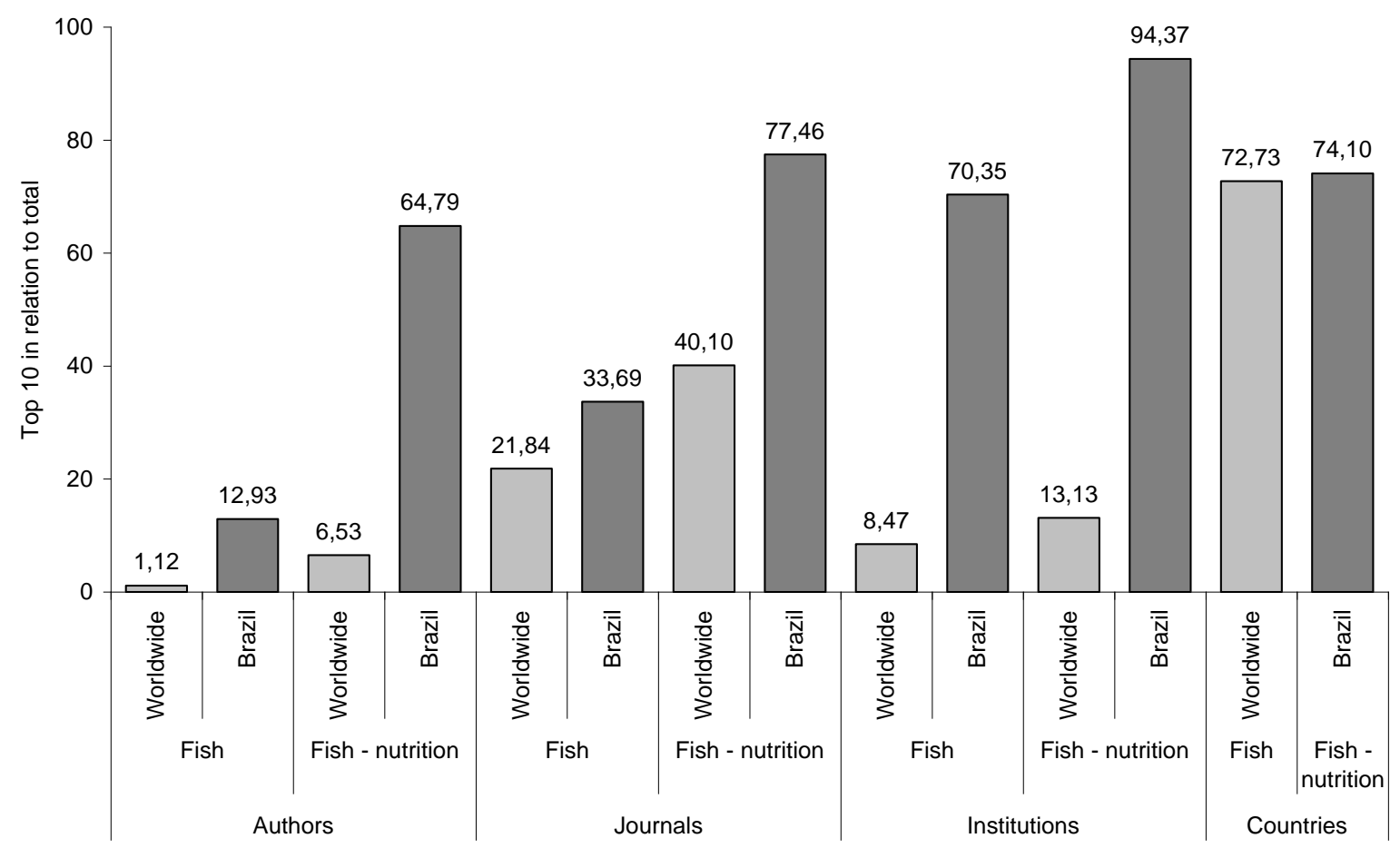

Graph 1: Share (\%) of publications of the top 10 authors, journals, institutions and countries on fish and fish nutrition in Brazil and worldwide.

From the exponential regression equations, it was prepared in Chart 2, which shows the annual average of growth rate. In 2000 to 2010, there was acceleration in the number of articles published in the world. In Brazil, the growth rate was much higher than in the world. The yearly growth rate in the world publications in fish nutrition area was $2.5 \%$, while the Brazil was $25.5 \%$, which is almost 10 times higher than the growth rate in the world. These data show how the scientific environment in fish nutrition area devoted to define the nutritional requirements of various species of exotic and native fish in Brazil. Research these important for the development of aquaculture, fastest growing sector in Brazil and the world. 


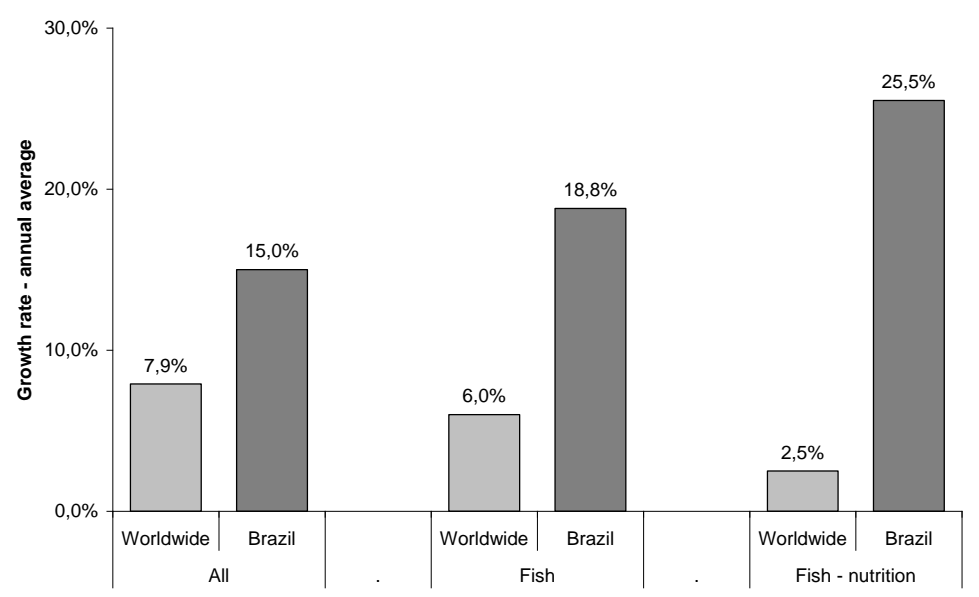

Graph 2: Yearly growth rate $(2000-2010)$ of the number of articles related to area of fish and fish nutrition in the world and in Brazil.

The degree of concentration of the articles published in the field of fish and fish nutrition of the top 10 authors, journals, institutions and countries in the world and in Brazil are presented in Table 5. It can observe that $12.93 \%$ of articles published in the fish area 10 were the authors who published, while in fish nutrition area close to this value is $65 \%$, showing that in fish nutrition research area are more concentrated when compared to the fish area.

Table 5: The degree of concentration of the articles published in the field of fish and fish nutrition of the top 10 authors, journals, institutions and countries worldwide and Brazil.

\begin{tabular}{llcccc}
\hline Item & Parameter & World & Brazh & \multicolumn{2}{c}{ Fish Nutrition } \\
& & 1407 & 477 & 91 & 46 \\
Authors & Total (10+) & 125598 & 3690 & 1394 & 71 \\
& Total & 1,12 & 12,93 & 6,53 & 64,79 \\
Journals & \%(10+) & 27431 & 1243 & 559 & 55 \\
& Total (10+) & 125598 & 3690 & 1394 & 71 \\
& Total & 21,84 & 33,69 & 40,10 & 77,46 \\
Institution & \%(10+) & 10639 & 2596 & 183 & 67 \\
& Total (10+) & 125598 & 3690 & 1394 & 71 \\
Country & Total & 8,47 & 70,35 & 13,13 & 94,37 \\
& \%(10+) & 91350 & - & 1033 & - \\
& Total (10+) & 125598 & - & 1394 & - \\
\hline
\end{tabular}

The total number of publications in the world was of 33,950,910 articles (Table 6), and those Brazil had a share with 397,330 articles, representing $1.17 \%$ of the total published in the world, leaving Brazil in $17^{\text {th }}$ of the countries that has published in this area, as can also be seen in graph 3. But when it comes to publications in fish nutrition area, Brazil occupies the 7th place of the countries that have published, that is, showing the great importance that the country has the global context in fish nutrition area. 
Table 6: Participation (\%) of publications in Brazil compared to the total published in the world in the areas of fish, fish nutrition and total publications.

\begin{tabular}{ccccc}
\hline Item & $\begin{array}{c}\text { World } \\
\mathbf{N}^{\mathbf{0}} \text { articles }\end{array}$ & $\mathbf{N}^{\mathbf{0}}$ articles & $\begin{array}{c}\text { Brazil } \\
\text { \% }\end{array}$ & Ranking \\
\hline All & 33950910 & 397330 & 1,17 & 17 \\
Fish & 125598 & 3690 & 2,94 & 10 \\
Fish - nutrition & 1394 & 71 & 5,09 & 7 \\
\hline
\end{tabular}
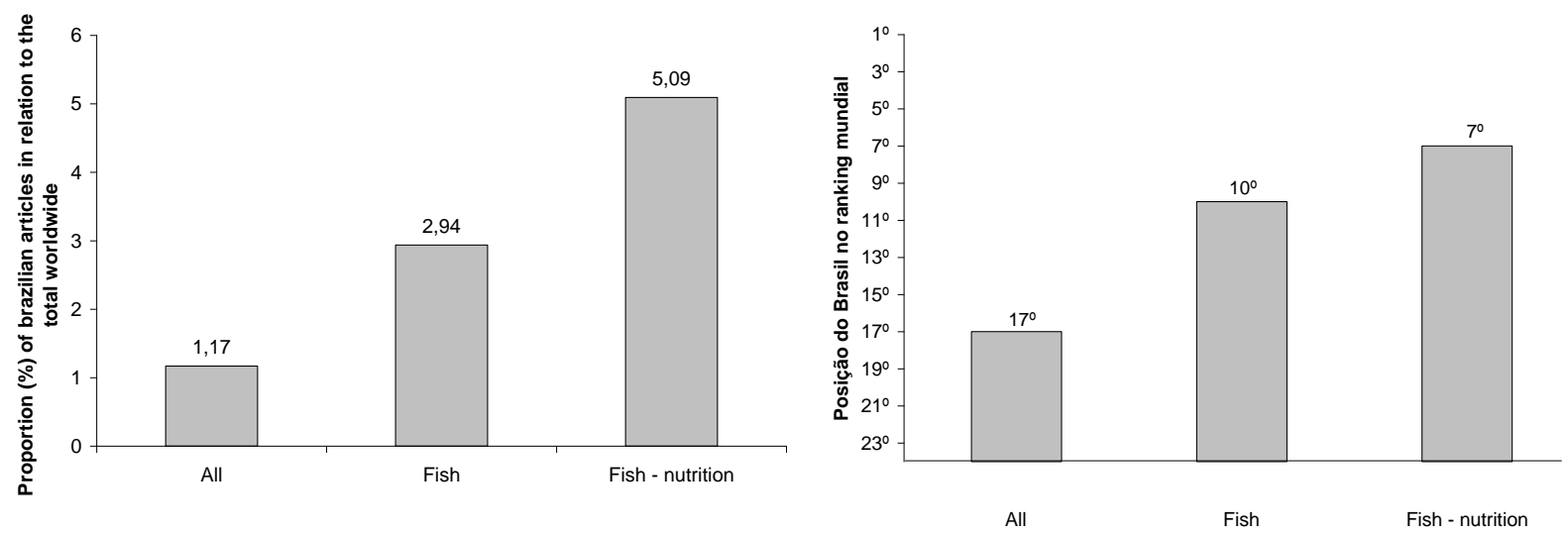

Graph 3: Share (\%) of the publications in Brazil compared to the total published worldwide in the areas of fish, fish nutrition and total publications.

Much research has to be developed in this area because most of the information available in the literature was obtained with species of cold water fish, whose reports cannot be adequately applied. The actual nutritional requirements of tropical fish species present unknown, which is probably the main challenge for the coming years and new researchers.

\section{Conclusions}

Based on bibliometric study on fish nutrition conducted, it was possible to obtain the following conclusions:

- The United States is the country that publishes more articles, while Brazil holds a prominent position in number of articles on the subject;

- Worldwide, the growth rate of articles has increased and, in Brazil, this growth rate is even higher, remaining high in recent years;

- Brazil's participation compared to world production in publications on the subject has increased exponentially;

- In Brazil, there is high concentration of articles in the top 10 authors, institutions and journals;

- Most of the articles on the subject in Brazil is published in the zootechnical field and in national magazines, contrary to Articles worldwide who are mostly published in journals in the field of fish nutrition and fish;

- Brazil has a university (UNESP) as a centre of excellence for publications in the area. 


\section{Acknowledgements}

The authors express their thanks to the Federal Institute of the Holy Spirit - IFES for the collaboration with the translation of the article. The State University of North Fluminense UENF the opportunity of realization of doctoral work and Higher Education Personnel Improvement Coordination - CAPES for granted doctoral scholarship.

\section{References}

ARAÚJO, Carlos Alberto. Bibliometria: evolução histórica e questões atuais. Em Questão, Porto Alegre, v. 12, n. 1, p. 11-32, jan./jun. 2006.

BOUSTANY, Joumana. La production des imprimés non-périodiques au Liban de 1733 à 1920: étude bibliométrique. 1997. Tese (Doutorado em Sciences de l'Information et de la Communication ) - Université Michel de Montaigne - Bordeaux III, Bordeaux. 1997

BRAGA, G. M. Dynamics of scientific communication: an application to Science funding policy. Cleveland, Case Western Reserve University, 1977. Doctoral thesis.

FONSECA, Edson Nery da (Org). Bibliometria: teoria e prática. São Paulo: Cultrix, Ed. da USP, 1986.

MEIS, L. et al. Uso de indicadores exige cautela. Folha de São Paulo, São Paulo, 12 set. 1999. Caderno Especial Ranking da Ciência, p. 7.

OLIVEIRA, A.. C.; DÓREA, J. G.; DOMENE, S. M. A. Bibliometria na avaliação da produção científica da área de nutrição registrada no Cibran: período de 1984-1989. Ciência da Informação, Brasília, v. 21, n. 3, p. 239-242, set./dez. 1992.

PINHEIRO, Lena Vânia Ribeiro. Lei de Bradford: uma reformulação conceitual. Ci. Inf., Brasília, v. 12, n. 2, p. 59-80, 1983.

PORTZ, L. Utilização de diferentes fontes protéicas em dietas formuladas pelo conceito de proteína ideal para o "Black Bass" (Micropterus salmoides). 2001a. 111f. Tese (Doutorado) Escola Superior de Agricultura "Luiz de Queiroz", Universidade de São Paulo, Piracicaba, SP.

PRITCHARD, A. Statistical bibliography or bibliometrics? J. Docum., 25 (4): 348-49, Dec..1969.

ROSTAING, Hervé. La bibliométrie et ses techniques. Tolouse: Sciences de la Société, 1996. $131 \mathrm{p}$.

TAGUE-SUTCKIFFE, J. An introduction to informetrics. Information Processing \& Management, v. 28, n. 1, p. 1-3, 1992. 